\title{
Lebetimonas acidiphila gen. nov., sp. nov., a novel thermophilic, acidophilic, hydrogen-oxidizing chemolithoautotroph within the 'Epsilonproteobacteria', isolated from a deep-sea hydrothermal fumarole in the Mariana Arc
}

\author{
Ken Takai, ${ }^{1}$ Hisako Hirayama, ${ }^{1}$ Tatsunori Nakagawa, ${ }^{1}$ Yohey Suzuki, ${ }^{1}$ \\ Kenneth $\mathrm{H}$. Nealson ${ }^{1,2}$ and Koki Horikoshi ${ }^{1}$ \\ ${ }^{1}$ Subground Animalcule Retrieval (SUGAR) Project, Japan Agency for Marine-Earth Science \\ and Technology, 2-15 Natsushima-cho, Yokosuka 237-0061, Japan \\ ${ }^{2}$ Department of Earth Sciences, University of Southern California, 3651 Trousdale Pkwy, \\ Los Angeles, CA 90089-0740, USA
}

Correspondence

Ken Takai

kent@jamstec.go.jp
An increasing number of successful isolations and characterizations of previously uncultivated 'Epsilonproteobacteria' in deep-sea hydrothermal environments has established a new insight into their physiological diversity as extremophiles (Alain et al., 2002; Campbell et al., 2001; Inagaki et al., 2003, 2004; Miroshnichenko et al., 2002, 2004; Takai et al., 2003a, 2004a). Nautilia lithotrophica strain $525^{\mathrm{T}}$ (Miroshnichenko et al., 2002) and Caminibacter hydrogeniphilus strain $\mathrm{AM} 1116^{\mathrm{T}}$ (Alain et al., 2002)

Published online ahead of print on 6 August 2004 as DOI 10.1099/ ijs.0.63330-0.

Abbreviations: EPR, East Pacific Rise; MAR, Mid-Atlantic Ridge; STRISCS, self-temperature-recording in situ colonization system.

The GenBank/EMBL/DDBJ accession number for the 16S rRNA gene sequence of strain $\mathrm{Pd}^{\top} 5^{\top}$ is $\mathrm{AB} 167820$.

An electron micrograph of strain $\mathrm{Pd}^{\mathrm{T}} 5^{\top}$ (Fig. A) and graphs showing the effects of temperature, $\mathrm{pH}$ and $\mathrm{NaCl}$ concentration on the growth

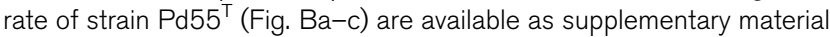
in IJSEM Online. are strictly anaerobic, hydrogen-oxidizing, thermophilic chemolithomixotrophs isolated from nests of tube-dwelling polychaetes of deep-sea hydrothermal systems in the East Pacific Rise (EPR). Other isolates (strains Am-H and EX18.2) from similar habitats have been reported as slightly thermophilic, anaerobic mixotrophs capable of using hydrogen as an energy source and elemental sulfur as a primary electron acceptor (Campbell et al., 2001). Together with a further isolate, Caminibacter profundus strain $\mathrm{CR}^{\mathrm{T}}$, from the Rainbow site in the Mid-Atlantic Ridge (MAR) (Miroshnichenko et al., 2004), a second order within the class 'Epsilonproteobacteria', in addition to the order 'Campylobacterales', has been proposed - the Nautiliales (Miroshnichenko et al., 2004). However, classification of 'Epsilonproteobacteria' at the order level is still unresolved since the previous phylogenetic analysis, justifying the paraphyletic lineages between 'Campylobacterales' and Nautiliales, did not include all the recently isolated subgroups of 'Epsilonproteobacteria' such as Group A (e.g. Hydrogenimonas thermophila strain EP1-55- $1 \%{ }^{\mathrm{T}}$ and others; 
Takai et al., 2003a, 2004a), Group F (e.g. Sulfurovum lithotrophicum strain $42 \mathrm{BKT}^{\mathrm{T}}$ and others; Inagaki et al., 2004; Takai et al., 2003a) and Group G (e.g. strain BKB25Ts-Y; Takai et al., 2003a). These strains are aerobic to anaerobic, hydrogen- and/or sulfur-oxidizing, strict chemolithoautotrophs representing a variety of microhabitats in deep-sea hydrothermal systems. As these isolates and the numerous uncultivated rRNA gene clones were not included in this recent analysis, phylogenetic organization of the 'Epsilonproteobacteria' is still uncertain. In addition, the taxonomic criteria of the orders Nautiliales and 'Campylobacterales' are unclear with respect to their coverage of the newly described genera and the numerous uncultivated phylotypes (Takai et al., 2003a, 2004b).

Probably, the confident taxonomy and systematics of 'Epsilonproteobacteria' require further exploration of asyet-uncultivated members and their phylogenetic and physiological traits in naturally occurring microbial habitats, specifically in the deep-sea hydrothermal and cold seeping environments, and subsurface biota. In this study, a novel thermophilic, acidophilic bacterium was isolated from a self-temperature-recording in situ colonization system (STR-ISCS) deployed in a hydrothermal diffusing flow (maximum temperature of $78{ }^{\circ} \mathrm{C}$ ) at the TOTO caldera in the Mariana Arc. Taxonomic characterization of this isolate, strain $\mathrm{Pd} 55^{\mathrm{T}}$, is described and a new genus and novel species, Lebetimonas acidiphila gen. nov., sp. nov., are proposed.

The STR-ISCS, a microbial habitat consisting of a stainless steel pipe with many small holes (5 $\mathrm{mm}$ diameter) and substratum of very porous natural pumice (Takai et al., 2003a), was deployed for 4 days in a diffusing hydrothermal flow with a maximum fluid temperature of $78^{\circ} \mathrm{C}$ and a pH of $5 \cdot 3$ at the TOTO caldera in the Mariana $\operatorname{Arc}\left(12^{\circ} 42 \cdot 8007^{\prime}\right.$ $\left.\mathrm{N} ; 143^{\circ} 32 \cdot 3415^{\prime} \mathrm{E}\right)$, at a depth of $2922 \mathrm{~m}$ by means of the manned submersible Shinkai 6500 (dive no. 772) in August 2003. After deployment, it was recovered to the sea surface in a sample box from the submersible (dive no. 776). The in situ temperature of the hydrothermal fluid was measured by a self-temperature-recording thermometer (Rigosya) and the $\mathrm{pH}$ of the hydrothermal fluid was obtained in the onboard laboratory immediately after recovery using a gastight fluid sampler 'WHATS' (Water Hydrothermal-fluid Atsuryoku Tight Sampler) (Tsunogai et al., 2002).

The TOTO caldera deep-sea hydrothermal field in the Mariana Arc was discovered by Gamo et al. (2004) in 1999. Previous physical and chemical characterization of the hydrothermal fluid has suggested that the TOTO caldera deep-sea hydrothermal activity is accompanied by highly acidic hydrothermal fluids resulting from oxidation of volatile volcanic gas $\left(\mathrm{H}_{2} \mathrm{~S}\right)$ to sulfate (Gamo et al., 2004). During a series of dive expeditions, a white-smoker hydrothermal vent with the lowest recorded $\mathrm{pH}$ value ( $\mathrm{pH} \mathrm{1.6)} \mathrm{was} \mathrm{found} \mathrm{in} \mathrm{the} \mathrm{TOTO} \mathrm{caldera,} \mathrm{which} \mathrm{reveals} \mathrm{that}$ the deep-sea hydrothermal activity in the TOTO caldera is a novel system driven by sub-seafloor mixing between the oxygenated sea water and the superheated volcanic gas, as proposed previously in the DESMOS caldera in the Manus Basin (Gamo et al., 1997). The STR-ISCS was deployed in one of the diffusing hydrothermal flows derived from the highly acidic hydrothermal fluid with further dilution of sea water. Thus, TOTO caldera hydrothermal activity is comparable to fumarole activity in terrestrial volcanoes and geothermal fields and this hydrothermal field may be described as a deep-sea hydrothermal fumarole. During the 4-day deployment, the temperature of the substratum in the colonization device shifted. The temperature fluctuated between 20 and $40^{\circ} \mathrm{C}$ in the first $24 \mathrm{~h}$, but gradually increased to $70{ }^{\circ} \mathrm{C}$ in the next $24 \mathrm{~h}$. Finally, the temperature was stable at $65-70{ }^{\circ} \mathrm{C}$ for the last 2 days.

Immediately after recovery of the STR-ISCS on the ship, a portion of substratum (approx. $1 \mathrm{~g}$ wet weight) was suspended in $20 \mathrm{ml}$ sterilized MJ synthetic sea water (Takai et al., 1999) containing $0.05 \%(\mathrm{w} / \mathrm{v})$ sodium sulfide in a $100 \mathrm{ml}$ glass bottle (Schott Glaswerke) and tightly sealed with a butyl-rubber cap under a gas phase of $100 \% \mathrm{~N}_{2}$ $(100 \mathrm{kPa})$. The suspended slurry was used to inoculate a series of media, including MJAIS-YTF medium [MJAIS medium (Takai et al., 2003c) supplemented with yeast extract, tryptone, formate and other components under a gas phase of $\mathrm{H}_{2}: \mathrm{CO}_{2}(80: 20 ; 200 \mathrm{kPa})$; described below]. Cultures were incubated at $55^{\circ} \mathrm{C}$ in a dry oven.

Growth of motile, short rods was observed in MJAIS-YTF medium after 2 days incubation at $55^{\circ} \mathrm{C}$. A pure culture was obtained using the dilution-to-extinction technique at $55^{\circ} \mathrm{C}$ with the same medium used for the enrichment (Takai \& Horikoshi, 2000). The isolate was designated strain Pd55 ${ }^{\mathrm{T}}$. Purity was confirmed routinely by microscopic examination and repeated partial sequencing of the $16 \mathrm{~S}$ rRNA gene using several primers (Lane, 1991).

Cells were observed under a phase-contrast Olympus BX51 microscope with the SPOT RT Slider CCD camera system (Diagnostic Instruments). The Gram staining test was performed with a Gram Stain kit (Wako). Transmission electron microscopy of negatively stained cells was carried out as described by Zillig et al. (1990). Cells grown in MJAIS-YTF medium under a gas phase of $\mathrm{H}_{2}: \mathrm{CO}_{2}(80: 20$; $200 \mathrm{kPa}$ ) at $55^{\circ} \mathrm{C}$ in the mid-exponential phase of growth were used for microscopic observation. Cells of strain Pd55 ${ }^{\mathrm{T}}$ were Gram-negative short rods, about $0 \cdot 6-0 \cdot 8 \mu \mathrm{m}$ in diameter, $1 \cdot 5-2 \cdot 5 \mu \mathrm{m}$ in length and motile with a polar flagellum (see Fig. A available as supplementary material in IJSEM Online). Spore formation was not observed under any of the culture conditions. The morphological features of strain Pd55 $5^{\mathrm{T}}$ were similar to those of previously described thermophilic 'Epsilonproteobacteria', N. lithotrophica strain $525^{\mathrm{T}}$ (Miroshnichenko et al., 2002), C. hydrogeniphilus

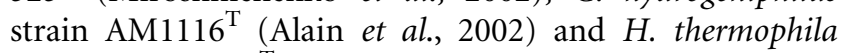
strain EP1-55-1\% ${ }^{\mathrm{T}}$ (Takai et al., 2004a).

Strain $\mathrm{Pd} 55^{\mathrm{T}}$ was routinely cultivated in MJAIS-YTF medium. To prepare MJAIS-YTF medium, the MJAIS components plus $0 \cdot 1 \%(\mathrm{w} / \mathrm{v})$ yeast extract, $0 \cdot 1 \%(\mathrm{w} / \mathrm{v})$ 
tryptone and $0.02 \%(\mathrm{w} / \mathrm{v})$ formate were dissolved and the $\mathrm{pH}$ of the medium was adjusted to around $\mathrm{pH} 5 \cdot 0$ with $\mathrm{HCl}$ before autoclaving. After autoclaving under an air atmosphere, a concentrated vitamin solution (Balch et al., 1979) and $\mathrm{NaHCO}_{3}$, elemental sulfur and $\mathrm{Na}_{2} \mathrm{~S}$ (Takai et al., 2003c) ( $\mathrm{pH}$ adjusted to $7 \cdot 0$ ) were added to the medium under gas purging of $80 \% \mathrm{H}_{2}$ and $20 \% \mathrm{CO}_{2}$ and the $\mathrm{pH}$ was re-adjusted to $\mathrm{pH} 5 \cdot 0$ with $\mathrm{HCl}$, unless otherwise noted. The four aforementioned components were separately sterilized by autoclaving except for the vitamin solution and elemental sulfur, which were filter- and steam-sterilized (three times at $95^{\circ} \mathrm{C}$ for $3 \mathrm{~h}$ ), respectively. The medium was dispensed at $20 \%$ total bottle (Schott Glaswerke) or tube (Iwaki Glass) volume, tightly sealed with a butyl-rubber stopper under a gas phase consisting of $80 \% \mathrm{H}_{2}$ and $20 \% \mathrm{CO}_{2}$ at $200 \mathrm{kPa}$. All experiments described below were conducted in duplicate.

Growth of strain $\mathrm{Pd} 55^{\mathrm{T}}$ was measured by direct cell counting after staining with 4',6-diamidino-2-phenylindole (Porter \& Feig, 1980) using a phase-contrast Olympus BX51 microscope. The cultures were grown in $100 \mathrm{ml}$ glass bottles (Schott Glaswerke) each containing $20 \mathrm{ml}$ medium with shaking (100 r.p.m.) in a temperature-controlled dry oven. With MJAIS-YTF medium, strain $\mathrm{Pd} 55^{\mathrm{T}}$ grew over the temperature range of about $30-68^{\circ} \mathrm{C}$, showing optimal growth at $50{ }^{\circ} \mathrm{C}$; the generation time at $50^{\circ} \mathrm{C}, \mathrm{pH} 5 \cdot 0$, was about $120 \mathrm{~min}$ (see Fig. Ba, available as supplementary material in IJSEM Online). The effect of initial $\mathrm{pH}$ on growth was tested at $50{ }^{\circ} \mathrm{C}$ using MJAIS-YTF medium adjusted to various $\mathrm{pH}$ levels with $10 \mathrm{mM}$ acetate/acetic acid buffer (pH 3-5), MES (pH 5-6), PIPES (pH 6-7) and HEPES ( $\mathrm{pH} 7 \cdot 0-7 \cdot 5$ ) at room temperature (see Fig. Bb, available as supplementary material in IJSEM Online). Growth occurred at initial $\mathrm{pH} 4 \cdot 2-7 \cdot 0$, with optimum growth at about pH $5 \cdot 2$ (see Fig. $\mathrm{Bb}$ ). No growth was observed below initial $\mathrm{pH} 3 \cdot 4$ or above initial $\mathrm{pH} 7 \cdot 2$. When the initial $\mathrm{pH}$ was $4 \cdot 2-5 \cdot 2$, the $\mathrm{pH}$ of the medium increased during cultivation (final $\mathrm{pH} 5 \cdot 7$ ) (see Fig. $\mathrm{Bb}$ ); however, the growth rate was determined in the early-exponential phase of growth and the effect of $\mathrm{pH}$ shift on growth was negligible. Strain Pd55 ${ }^{\mathrm{T}}$, when tested in MJAIS-YTF medium with variable amounts of $\mathrm{NaCl}$ added, grew in $6-50 \mathrm{~g} \mathrm{NaCl} \mathrm{l}^{-1}$, with optimum growth at $20 \mathrm{~g} \mathrm{NaCl} \mathrm{l}^{-1}$, $50^{\circ} \mathrm{C}$ and $\mathrm{pH} 5 \cdot 0$ (see Fig. Bc, available as supplementary material in IJSEM Online). In general, the temperature and salt requirements of $\mathrm{Pd} 55^{\mathrm{T}}$ were similar to those of $N$. lithotrophica strain $525^{\mathrm{T}}$, C. hydrogeniphilus strain AM1116 and H. thermophila strain EP1-55-1\% ${ }^{\mathrm{T}}$ (Table 1). However, the acidophilic growth of strain $\mathrm{Pd} 55^{\mathrm{T}}$ was a novel physiological feature within the previously described thermophilic epsilonproteobacterial genera.

The susceptibility of strain $\mathrm{Pd} 55^{\mathrm{T}}$ to molecular oxygen was tested with MJAIS-YTF medium under gas mixtures of $\mathrm{H}_{2}: \mathrm{CO}_{2}: \mathrm{O}_{2}(800: 199: 1,800: 195: 5$ and $800: 190: 10)$ at $200 \mathrm{kPa}$. Strain $\mathrm{Pd} 55^{\mathrm{T}}$ grew only under strict anaerobic culture conditions and was extremely sensitive to oxygen.

Table 1. Comparison of properties of strain $\mathrm{Pd5} 55^{\top}$ with those of closely related species

Strains: 1, Lebetimonas acidiphila gen. nov., sp. nov. strain $\mathrm{Pd} 55^{\mathrm{T}}$ (data from this study); 2, N. lithotrophica strain $525^{\mathrm{T}}$ (Miroshnichenko et al., 2002); 3, C. hydrogeniphilus strain AM1116 ${ }^{\mathrm{T}}$ (Alain et al., 2002); 4, C. profundus strain $\mathrm{CR}^{\mathrm{T}}$ (Miroshnichenko et al., 2004); 5, H. thermophilus strain EP1-55-1\% ${ }^{\mathrm{T}}$ (Takai et al., 2004a).

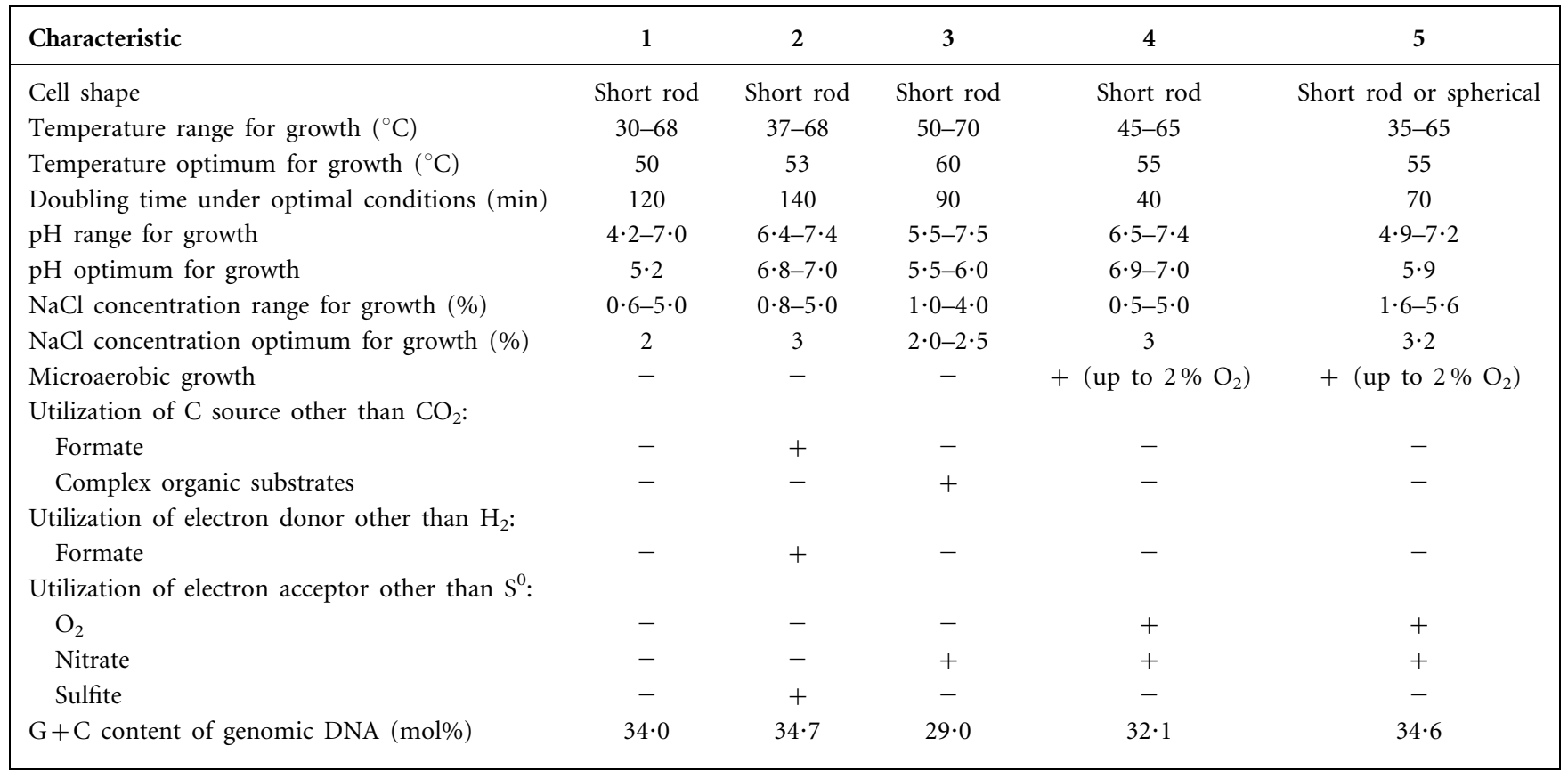


Strictly autotrophic growth was examined in MJAIS-YTF medium lacking yeast extract, tryptone and formate under a gas phase of $80 \% \mathrm{H}_{2}$ and $20 \% \mathrm{CO}_{2}(200 \mathrm{kPa})$. Strain Pd55 was able to grow under strict chemolithoautotrophic conditions with $\mathrm{H}_{2}$ and $\mathrm{S}^{0}$ as the sole electron donor and acceptor, respectively. The maximal cell yield under strict chemolithoautotrophic conditions was almost the same as

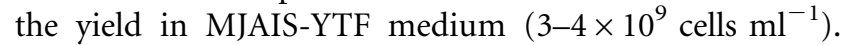
However, when strain $\mathrm{Pd} 55^{\mathrm{T}}$ was grown under strict chemolithoautotrophic conditions with $\mathrm{H}_{2}$ and $\mathrm{S}^{0}$, the culturability of the cells after growth was significantly reduced, i.e. the proportion of the culturable cell number after growth decreased to $10^{-5}$ of that in MJAIS-YTF medium. Culturability was examined in a series of $10^{-1}$ dilution cultivations with the strictly autotrophic medium or MJAIS-YTF medium. An improvement in culturability was observed by addition of $0 \cdot 1 \%(\mathrm{w} / \mathrm{v})$ yeast extract, $0 \cdot 1 \%$ $(\mathrm{w} / \mathrm{v})$ tryptone, $0 \cdot 1 \%(\mathrm{w} / \mathrm{v})$ Casamino acids, $5 \mathrm{mM}$ formate, $5 \mathrm{mM}$ acetate, $5 \mathrm{mM}$ citrate, $5 \mathrm{mM}$ tartrate, $5 \mathrm{mM}$ fumarate, $5 \mathrm{mM}$ succinate, $5 \mathrm{mM}$ malate, $5 \mathrm{mM}$ lactate or $5 \mathrm{mM}$ pyruvate to the strictly autotrophic medium. Heterotrophic growth was determined in MJAIS-YTF medium lacking $\mathrm{NaHCO}_{3}$, yeast extract, tryptone and formate under a gas phase of $100 \% \mathrm{H}_{2}$ $(200 \mathrm{kPa})$, containing the following potential carbon sources: $0 \cdot 1 \%(\mathrm{w} / \mathrm{v})$ yeast extract, $0 \cdot 1 \%(\mathrm{w} / \mathrm{v})$ peptone, $0 \cdot 1 \%(\mathrm{w} / \mathrm{v})$ tryptone, $0 \cdot 1 \%(\mathrm{w} / \mathrm{v})$ Casamino acids, 1 and $5 \mathrm{mM}$ formate, $5 \mathrm{mM}$ acetate, $5 \mathrm{mM}$ glycerol, $0.025 \%$ $(\mathrm{v} / \mathrm{v})$ methanol, $0.05 \%(\mathrm{v} / \mathrm{v})$ ethanol, $0.1 \%(\mathrm{v} / \mathrm{v}) \quad 2-$ propanol, $5 \mathrm{mM}$ citrate, $5 \mathrm{mM}$ tartrate, $5 \mathrm{mM}$ fumarate, $5 \mathrm{mM}$ maleate, $5 \mathrm{mM}$ succinate, $5 \mathrm{mM}$ propionate, $5 \mathrm{mM}$ malate, $5 \mathrm{mM}$ lactate, $5 \mathrm{mM}$ oxalate, $5 \mathrm{mM}$ thioglycollate, $5 \mathrm{mM}$ pyruvate, $5 \mathrm{mM}$ each of 20 amino acids, $0 \cdot 1 \%(\mathrm{w} / \mathrm{v})$ glucose, $0 \cdot 1 \%(\mathrm{w} / \mathrm{v})$ galactose, $0 \cdot 1 \%(\mathrm{w} / \mathrm{v})$ sucrose, $0 \cdot 1 \%$ $(\mathrm{w} / \mathrm{v})$ fructose, $0 \cdot 1 \%(\mathrm{w} / \mathrm{v})$ lactose, $0 \cdot 1 \%(\mathrm{w} / \mathrm{v})$ maltose, $0 \cdot 1 \%(\mathrm{w} / \mathrm{v})$ arabinose, $0 \cdot 1 \%(\mathrm{w} / \mathrm{v})$ trehalose and $0 \cdot 1 \%$ $(\mathrm{w} / \mathrm{v})$ starch. Strain Pd $55^{\mathrm{T}}$ was not able to grow with any of the heterotrophic substrates using $\mathrm{H}_{2}$ as an energy source and $S^{0}$ as an electron acceptor. Utilization of these organic compounds as an alternative energy source instead of $\mathrm{H}_{2}$ was also examined in MJAIS-YTF medium lacking yeast extract, tryptone and formate under a gas phase of $80 \% \mathrm{~N}_{2}$ and $20 \% \mathrm{CO}_{2}(200 \mathrm{kPa})$. None of the organic compounds sustained growth of strain $\mathrm{Pd} 55^{\mathrm{T}}$. In an attempt to determine potential electron donors and acceptors other than a combination of $\mathrm{H}_{2}$ and $\mathrm{S}^{0}$ for autotrophic growth, each of the potential electron donors such as thiosulfate $(20 \mathrm{mM})$, sulfite $(5$ and $20 \mathrm{mM})$ or ferrous iron $(20 \mathrm{mM})$ was tested with nitrate $(10 \mathrm{mM})$ and fumarate $(10 \mathrm{mM})$ as the electron acceptors, and each of the potential electron acceptors such as sulfite $(2$ and $10 \mathrm{mM})$, thiosulfate $(10 \mathrm{mM})$, tetrathionate $(10 \mathrm{mM})$, nitrate $(10 \mathrm{mM})$, nitrite (1 and $5 \mathrm{mM})$, ferric citrate $(20 \mathrm{mM})$, selenate $(5 \mathrm{mM})$, arsenate $(5 \mathrm{mM})$ or fumarate $(10 \mathrm{mM})$ was tested with $\mathrm{H}_{2}$ as the electron donor. The anaerobic cultivation procedure in the absence of $\mathrm{Na}_{2} \mathrm{~S} .9 \mathrm{H}_{2} \mathrm{O}$ and in the presence of ferric citrate $(20 \mathrm{mM})$, selenate $(5 \mathrm{mM})$ or arsenate $(5 \mathrm{mM})$ has been described previously (Takai et al., 2003b). None of the combinations other than $\mathrm{H}_{2}$ and $\mathrm{S}^{0}$ supported growth of strain $\mathrm{Pd} 55^{\mathrm{T}}$. The potential nutrients required for growth such as selenite, tungstate and vitamins were examined under strict chemoautotrophic conditions in the absence of the test materials and the nitrogen source for growth $\left(\mathrm{NH}_{4} \mathrm{Cl}, \mathrm{NaNO}_{2}, \mathrm{~N}_{2}, \mathrm{NaNO}_{3}\right.$ or yeast extract) was also examined under strict autotrophic conditions. Strain Pd55 ${ }^{\mathrm{T}}$ utilized ammonium, nitrate and organic nitrogen compound as a nitrogen source, but could not utilize nitrite or molecular nitrogen. Selenium, tungsten and vitamins were not required for growth. These results indicate that strain $\mathrm{Pd} 55^{\mathrm{T}}$ was a strict chemolithoautotroph utilizing $\mathrm{H}_{2}$ as the sole electron donor, $\mathrm{S}^{0}$ as the sole electron acceptor and $\mathrm{CO}_{2}$ as the sole carbon source for growth. However, the presence of organic compounds strongly improved the culturability of strain $\mathrm{Pd} 55^{\mathrm{T}}$ although the mechanism is still unclear. Strain Pd55 $5^{\mathrm{T}}$ resembles N. lithotrophica strain $525^{\mathrm{T}}, C$. hydrogeniphilus strain AM $1116^{\mathrm{T}}$ and H. thermophila strain EP1-55-1\% ${ }^{\mathrm{T}}$ in utilization of molecular hydrogen as the primary electron donor, although it could not use formate as either energy or carbon source and it could not use any of the organic compounds tested as sole carbon source (Table 1). Other than $S^{0}, N$. lithotrophica strain $525^{\mathrm{T}}$ is able to utilize sulfite, C. hydrogeniphilus strain AM1116 ${ }^{\mathrm{T}}$ is able to utilize nitrate and $H$. thermophila strain $\mathrm{EP} 1-55-1 \%^{\mathrm{T}}$ is able to utilize nitrate and molecular oxygen as alternative electron acceptors (Table 1). Utilization of $S^{0}$ as the sole electron acceptor of strain Pd55 $5^{\mathrm{T}}$ differs markedly from the energy metabolisms of the previously described thermophilic genera within the 'Epsilonproteobacteria' (Table 1).

The time-course of the reduction of elemental sulfur and concomitant bacterial growth of strain $\mathrm{Pd} 55^{\mathrm{T}}$ were examined in MJAIS-YTF medium under a gas phase of $80 \% \mathrm{H}_{2}+20 \% \mathrm{CO}_{2}(200 \mathrm{kPa})$ (Fig. 1). The concentration of $\mathrm{H}_{2} \mathrm{~S}$ in the gas phase during growth was measured using a GC Micro GC CP2002 (GL Sciences). The gas phase was

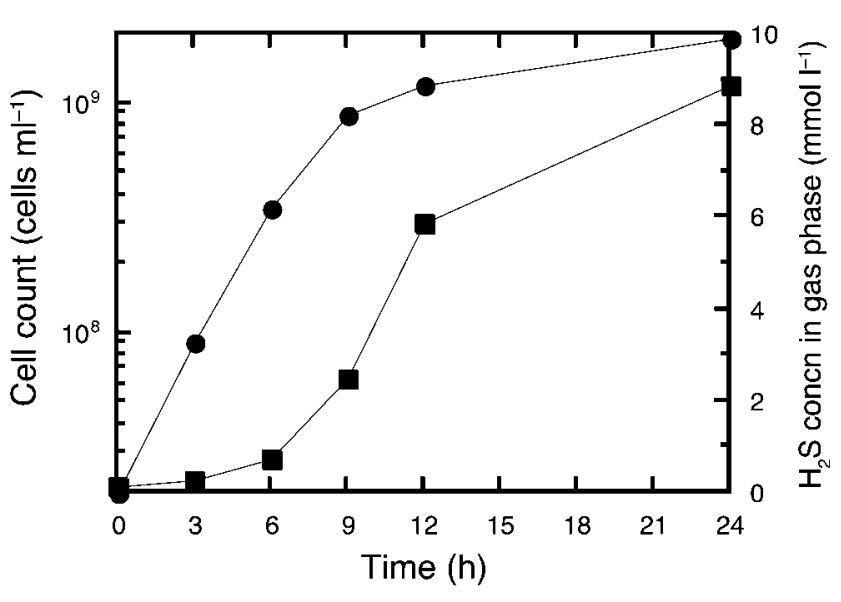

Fig. 1. Time-course of reduction of hydrogen sulfide in the gas phase ( $\boldsymbol{\square})$ and concomitant bacterial growth ( $)$ of Lebetimonas acidiphila strain $\mathrm{Pd} 55^{\top}$. 
periodically sampled with a $1 \mathrm{ml}$ gas-tight syringe, which was directly applied to the GC or diluted once with helium gas and then applied. The consumption of molecular hydrogen and elemental sulfur was not measured because of the large amounts of hydrogen and sulfur in the medium required for growth; however, the concentration of hydrogen sulfide increased during growth of strain Pd $55^{\mathrm{T}}$ (Fig. 1). Since the control medium that lacked a bacterial inoculum did not demonstrate reduction of elemental sulfur, bacterial reduction of elemental sulfur occurred during growth. Strain $\mathrm{Pd} 55^{\mathrm{T}}$ was found to be a respiratory hydrogen-oxidizing, sulfur-reducing chemolithoautotroph.

The sensitivity of strain $\mathrm{Pd} 55^{\mathrm{T}}$ to antibiotics such as chloramphenicol (50 and $\left.100 \mu \mathrm{g} \mathrm{ml}^{-1}\right)$, streptomycin (50 and $100 \mu \mathrm{g} \mathrm{ml}^{-1}$ ), kanamycin (50 and $100 \mu \mathrm{g} \mathrm{ml}^{-1}$ ), ampicillin (50 and $100 \mu \mathrm{g} \mathrm{ml}^{-1}$ ) and rifampicin (50 and $100 \mu \mathrm{g} \mathrm{ml}^{-1}$ ) was tested at $55^{\circ} \mathrm{C}$. Strain Pd5 $55^{\mathrm{T}}$ was sensitive to all the antibiotics tested at a concentration of $50 \mu \mathrm{g} \mathrm{ml}^{-1}$. Antibiotic susceptibility was similar in strain $\mathrm{Pd} 55^{\mathrm{T}}, \mathrm{N}$. lithotrophica strain $525^{\mathrm{T}}$ (Miroshnichenko et al., 2002) and H. thermophila strain EP1-55-1\% ${ }^{\mathrm{T}}$ (Takai et al., 2004a); C. hydrogeniphilus strain AM1116 (Alain et al., 2002) was resistant to kanamycin $\left(100 \mu \mathrm{g} \mathrm{ml}^{-1}\right)$.

The cellular fatty acid composition of cells grown in MJAISYTF medium at $55^{\circ} \mathrm{C}$ in the late-exponential phase of growth was analysed. Lyophilized cells $(100 \mathrm{mg})$ were placed in a Teflon-lined, screw-capped tube containing $3 \mathrm{ml}$ anhydrous methanolic $\mathrm{HCl}$ and heated at $100^{\circ} \mathrm{C}$ for $3 \mathrm{~h}$. The extraction and analysis of fatty acid methyl esters were as described previously (Takai et al., 2003b). The major cellular fatty acids of strain $\mathrm{Pd} 55^{\mathrm{T}}$ were $\mathrm{C}_{14: 0}(4 \cdot 3 \%), \mathrm{C}_{14: 0}$ $3-\mathrm{OH}(9 \cdot 8 \%), \mathrm{C}_{16: 0}(12 \cdot 5 \%), \mathrm{C}_{16: 1}(9 \cdot 7 \%), \mathrm{C}_{17: 0}(4 \cdot 4 \%)$, $\mathrm{C}_{18: 0}(26 \cdot 5 \%), \mathrm{C}_{18: 1}(22 \cdot 2 \%)$, anteiso- $\mathrm{C}_{19: 0}(4 \cdot 8 \%)$ and $\mathrm{C}_{19: 1}(5 \cdot 8 \%)$. This composition was generally similar to that of $H$. thermophila strain EP1-55-1\% ${ }^{\mathrm{T}}$ (Takai et al., 2004a), although the cellular fatty acids anteiso- $\mathrm{C}_{19: 0}$ $(4 \cdot 8 \%)$ and $\mathrm{C}_{19: 1}(5 \cdot 8 \%)$ were only present in strain Pd55 ${ }^{\mathrm{T}}$.

Genomic DNA of strain Pd55 ${ }^{\mathrm{T}}$ was prepared as described by Marmur \& Doty (1962). The G + C content of the DNA was determined by direct analysis of deoxyribonucleotides by HPLC (Tamaoka \& Komagata, 1984). The DNA G + C content of strain $\mathrm{Pd} 55^{\mathrm{T}}$ was $34 \cdot 0 \mathrm{~mol} \%$, which was similar to those of N. lithotrophica strain $525^{\mathrm{T}}$ and $H$. thermophila strain EP1-55-1\% ${ }^{\mathrm{T}}(34 \cdot 7$ and $34 \cdot 6 \mathrm{~mol} \%$, respectively), but higher than that of $C$. hydrogeniphilus strain AM1116 (29 mol\%) (Table 1).

The 16S rRNA gene was amplified by PCR using primers Bac27F and 1492R (DeLong, 1992; Lane, 1991), as described previously (Takai et al., 2001). The nearly complete sequence $(1431 \mathrm{bp})$ of the16S rRNA gene from strain $\operatorname{Pd} 55^{\mathrm{T}}$ was directly sequenced using both strands by the dideoxynucleotide chain-termination method with a DNA sequencer model 3100 (Perkin Elmer/Applied Biosystems). The rRNA gene sequence was analysed using the gappedBLAST search algorithm (Altschul et al., 1997; Benson et al.,
$1998)$ and was most closely related $(94 \cdot 4 \%)$ to the sequence of strain B455-1, isolated from a deep-sea hydrothermal environment in the Iheya North of the Okinawa Trough (Takai et al., 2003a). Similarities with the sequences of $C$. profundus strain $\mathrm{CR}^{\mathrm{T}}$ (Miroshnichenko et al., 2004) and $N$. lithotrophica strain $525^{\mathrm{T}}$ (Miroshnichenko et al., 2002), isolated from deep-sea hydrothermal systems in the MAR and EPR, respectively, were $92 \cdot 1$ and $92.0 \%$, respectively. The nearly complete sequence was manually re-aligned according to the secondary structures using ARB (Ludwig et al., 2004). Phylogenetic analyses were restricted to nucleotide positions that could be chosen using the $\varepsilon$-Proteobacteria filter of Hugenholtz (2002). Evolutionary distance matrix analysis (using the Jukes-Cantor correlation method) and neighbour-joining analysis were performed using ARB (Fig. 2). Bootstrap analysis was performed to provide confidence estimates for phylogenetic tree topologies. The phylogenetic tree indicated that strain $\mathrm{Pd} 55^{\mathrm{T}}$ represented a novel lineage together with strain B455-1 prior to divergence of the genera Nautilia and Caminibacter (Fig. 2).

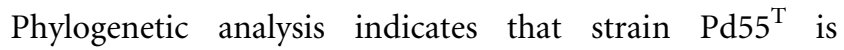
associated with the genera Nautilia and Caminibacter, which include not only the type species of N. lithotrophica strain $525^{\mathrm{T}}$ (Miroshnichenko et al., 2002) and C. hydrogeniphilus strain $\mathrm{AM} 1116^{\mathrm{T}}$ (Alain et al., 2002) from tubedwelling polychaetes nests of deep-sea hydrothermal systems in the EPR, but also the recently described species C. profundus strain $\mathrm{CR}^{\mathrm{T}}$ (Miroshnichenko et al., 2004) and the potential Nautilia spp. strains Am-H and EX-18.2 (Campbell et al., 2001). Similarity levels between the $16 \mathrm{~S}$ rRNA gene sequences of strain Pd55 $5^{\mathrm{T}}$ and either Nautilia $(92.0 \%)$ or Caminibacter $(92.1 \%)$ are within the common index of $16 \mathrm{~S}$ rRNA gene sequence similarities for genus-level differentiation (90-96\%) (Gillis et al., 2001). In addition, phylogenetic characterization demonstrates that strain $\mathrm{Pd} 55^{\mathrm{T}}$ represents a separate phylotype together with strain B455-1, which was isolated from the deep-sea hydrothermal environment in the Okinawa Trough (Takai et al., 2003a), diverging prior to differentiation of the genera Nautilia and Caminibacter. These results suggest that strain $\mathrm{Pd} 55^{\mathrm{T}}$ can be genetically classified as representing a new genus within the 'Epsilonproteobacteria'. The physiological properties of strain $\mathrm{Pd} 55^{\mathrm{T}}$ reinforce differentiation from Nautilia and Caminibacter at the genus level (Table 1). Strain Pd55 grows optimally at much lower $\mathrm{pH}(5 \cdot 2)$ and is able to grow in a much more acidic $\mathrm{pH}$ range $(\mathrm{pH} 4 \cdot 2-7 \cdot 0)$ than $N$. lithotrophica strain $525^{\mathrm{T}}$, C. hydrogeniphilus strain $\mathrm{AM}_{1116^{\mathrm{T}}}$ and C. profundus strain $\mathrm{CR}^{\mathrm{T}}$ (Table 1). Hydrogen-dependent energy metabolism is common among the previously described members of the genera Nautilia and Caminibacter, whereas strain $\mathrm{Pd} 55^{\mathrm{T}}$ is an obligate chemolithoautotroph and can utilize only elemental sulfur as an electron acceptor (Table 1). On the basis of these physiological and molecular properties of strain $\mathrm{Pd} 55^{\mathrm{T}}$, a new genus, Lebetimonas gen. nov., is proposed. Strain Pd55 $5^{\mathrm{T}}\left(=\mathrm{JCM} 12420^{\mathrm{T}}=\right.$ DSM $\left.16356^{\mathrm{T}}\right)$ is proposed as 


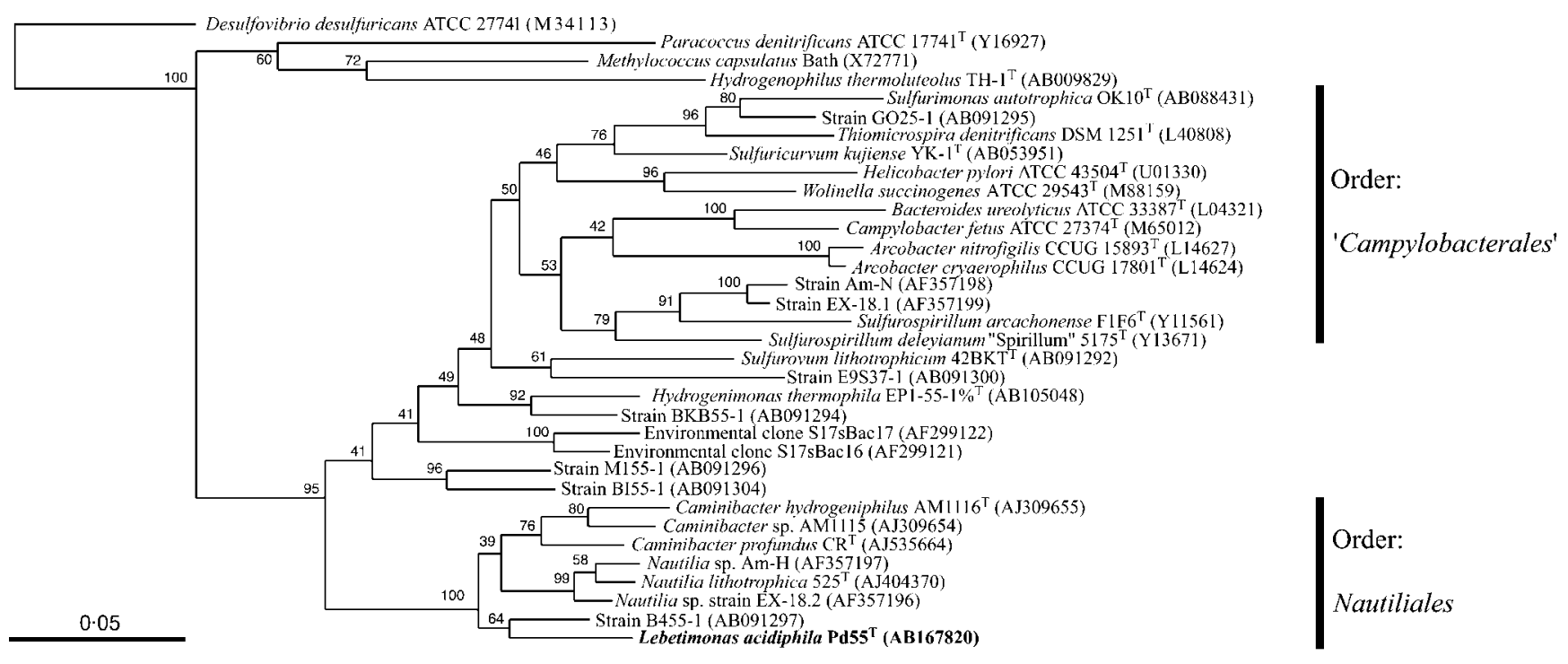

Fig. 2. Phylogenetic tree of representative 'Epsilonproteobacteria' strains and environmental rRNA gene clones inferred from 16S rRNA gene sequences using the neighbour-joining method on the 1208 homologous sequence positions for each organism. The number at each node represents the bootstrap value (100 replicates). Bar, 5 substitutions per $100 \mathrm{nt}$.

the type strain of a novel species in this genus, Lebetimonas acidiphila sp. nov.

\section{Description of Lebetimonas gen. nov.}

Lebetimonas (Le.be.ti.mo' nas. L. n. lebes cauldron; L. fem. n. monas a unit, monad; N.L. fem. n. Lebetimonas cell from a cauldron).

Short rods, motile with a polar flagellum. Gram-negative. Strictly anaerobic. Thermophilic and acidophilic. Strictly chemolithoautotrophic. Able to utilize molecular hydrogen as an electron donor and elemental sulfur as an electron acceptor. $\mathrm{NaCl}$ absolutely required for growth. $\mathrm{G}+\mathrm{C}$ content of genomic DNA is about $34 \mathrm{~mol} \%$. Major cellular fatty acids are $\mathrm{C}_{18: 0}$ and $\mathrm{C}_{18: 1}$. On the basis of $16 \mathrm{~S}$ rRNA gene analysis, the genus Lebetimonas is related to the genera Nautilia and Caminibacter within the 'Epsilonproteobacteria'. Members of the genus Lebetimonas occur in global deep-sea hydrothermal systems.

The type species is Lebetimonas acidiphila.

\section{Description of Lebetimonas acidiphila sp. nov.}

Lebetimonas acidiphila (a.ci.di' phi.la. L. adj. acidus, - $a$, -um sour; N.L. n. acidum acid; Gr. adj. philos loving; N.L. fem. adj. acidiphila acid-loving).

Each cell is a highly motile rod with a polar flagellum and a mean length of $1.5-2.5 \mu \mathrm{m}$ and width of approximately $0 \cdot 6-0 \cdot 8 \mu \mathrm{m}$. Cells occur singly. Gram-negative. Strictly anaerobic. The temperature range for growth is $30-68{ }^{\circ} \mathrm{C}$ (optimum $50{ }^{\circ} \mathrm{C}$ ). The $\mathrm{pH}$ range for growth is $4 \cdot 2-7 \cdot 0$ (optimum $\mathrm{pH} 5 \cdot 2$ ). $\mathrm{NaCl}$ at $6-50 \mathrm{~g} \mathrm{l}^{-1}$ is an absolute growth requirement; optimum growth occurs at $20 \mathrm{~g} \mathrm{l}^{-1}$. Strict chemolithoautotrophic growth occurs with molecular hydrogen as an electron donor and with elemental sulfur as an electron acceptor. Elemental sulfur is reduced to hydrogen sulfide during growth. Nitrate or ammonium is required as a nitrogen source. Vitamins, selenium and tungsten are not required for growth. The major cellular fatty acids are $\mathrm{C}_{14: 0}(4 \cdot 3 \%), \mathrm{C}_{14: 0} 3-\mathrm{OH}(9 \cdot 8 \%), \mathrm{C}_{16: 0}$ $(12 \cdot 5 \%), \mathrm{C}_{16: 1}(9 \cdot 7 \%), \mathrm{C}_{17: 0}(4 \cdot 4 \%), \mathrm{C}_{18: 0}(26 \cdot 5 \%)$, $\mathrm{C}_{18: 1}(22 \cdot 2 \%)$, anteiso- $\mathrm{C}_{19: 0}(4 \cdot 8 \%)$ and $\mathrm{C}_{19: 1}(5 \cdot 8 \%)$.

The type strain is $\operatorname{Pd} 55^{\mathrm{T}}\left(=\mathrm{JCM} 12420^{\mathrm{T}}=\mathrm{DSM} 16356^{\mathrm{T}}\right)$, isolated from an in situ colonization system deployed in a hydrothermal diffusing flow (maximum temperature of $78^{\circ} \mathrm{C}$ ) at the TOTO caldera in the Mariana Arc. The DNA $\mathrm{G}+\mathrm{C}$ content of strain $\mathrm{Pd} 55^{\mathrm{T}}$ is $34 \cdot 0 \mathrm{~mol} \%$ (by HPLC).

\section{Acknowledgements}

We would like to thank Dr Katsuyuki Uematsu for assistance in preparing electron micrographs. We are very grateful to the $R / V$ Yokosuka and the Shinkai 6500 operation teams for helping us to collect deep-sea hydrothermal vent samples.

\section{References}

Alain, K., Querellou, J., Lesongeur, F., Pignet, P., Crassous, P., Raguénès, G., Cueff, V. \& Cambon-Bonavita, M.-A. (2002). Caminibacter hydrogeniphilus gen. nov., sp. nov., a novel thermophilic, hydrogen-oxidizing bacterium isolated from an East Pacific Rise hydrothermal vent. Int J Syst Evol Microbiol 52, 1317-1323.

Altschul, S. F., Madden, T. L., Schaffer, A. A., Zhang, J., Zhang, Z., Miller, W. \& Lipman, D. J. (1997). Gapped BLAST and PSI-BLAST: a new generation of protein database search programs. Nucleic Acids Res 25, 3389-3402. 
Balch, W. E., Fox, G. E., Magrum, L. J., Woese, C. R. \& Wolfe, R. S. (1979). Methanogens: re-evaluation of a unique biological group. Microb Rev 43, 260-296.

Benson, D. A., Boguski, M. S., Lipman, D. J., Ostell, J. \& Ouellette, B. F. F. (1998). GenBank. Nucleic Acids Res 26, 1-7.

Campbell, B. J., Jeanthon, C., Kostka, J. E., Luther, G. W., III \& Cary, S. C. (2001). Growth and phylogenetic properties of novel bacteria belonging to the epsilon subdivision of the Proteobacteria enriched from Alvinella pompejana and deep-sea hydrothermal vents. Appl Environ Microbiol 67, 4566-4572.

DeLong, E. F. (1992). Archaea in coastal marine environments. Proc Natl Acad Sci U S A 89, 5685-5689.

Gamo, T., Okamura, K., Charlou, J.-L., Urabe, T., Auzende, J.-M., Ishibashi, J., Shitashima, K. \& Kodama, Y. (1997). Acidic and sulfate-rich hydrothermal fluid from the Manus Basin, Papua New Guinea. Geology 25, 139-142.

Gamo, T., Masuda, H., Yamanaka, T. \& 13 other authors (2004). Discovery of a new hydrothermal venting site in the southernmost Mariana Arc: Al-rich hydrothermal plumes and white smoker activity associated with biogenic methane. Geochemical $J$ (in press).

Gillis, M., Vandamme, P., De Vos, P., Swings, J. \& Kersters, K. (2001). Polyphasic taxonomy. In Bergey's Manual of Systematic Bacteriology, 2nd edn, pp. 43-48. Edited by D. R. Boone \& R. W. Castenholz. New York: Springer.

Hugenholtz, P. (2002). Exploring prokaryotic diversity in the gemonic era. Genome Biol 3, REVIEWS0003.

Inagaki, F., Takai, K., Kobayashi, H., Nealson, K. H. \& Horikoshi, K. (2003). Sulfurimonas autotrophica gen. nov., sp. nov., a novel sulfuroxidizing $\varepsilon$-proteobacterium isolated from hydrothermal sediments in the Mid-Okinawa Trough. Int J Syst Evol Microbiol 53, 1801-1805.

Inagaki, F., Takai, K., Nealson, K. H. \& Horikoshi, K. (2004). Sulfurovum lithotrophicum gen. nov., sp. nov., a novel sulfuroxidizing chemolithoautotroph within the $\varepsilon$-Proteobacteria isolated from Okinawa Trough hydrothermal sediments. Int J Syst Evol Microbiol 54, 1477-1482.

Lane, D. J. (1991). 16S/23S sequencing. In Nucleic Acid Techniques in Bacterial Systematics, pp. 115-176. Edited by E. Stackebrandt \& M. Goodfellow. New York: Wiley.

Ludwig, W., Strunk, O., Westram, R. \& 29 other authors (2004). ARB: a software environment for sequence data. Nucleic Acids Res 32, 1363-1371.

Marmur, J. \& Doty, P. (1962). Determination of the base composition of deoxyribonucleic acid from its thermal denaturation temperature. J Mol Biol 5, 109-118.

Miroshnichenko, M. L., Kostrikina, N. A., L'Haridon, S., Jeanthon, C., Hippe, H., Stackebrandt, E. \& Bonch-Osmolovskaya, E. A. (2002). Nautilia lithotrophica gen. nov., sp. nov., a thermophilic sulfurreducing $\varepsilon$-proteobacterium isolated from a deep-sea hydrothermal vent. Int J Syst Evol Microbiol 52, 1299-1304.

Miroshnichenko, M. L., L'Haridon, S., Schumann, P., Spring, S., Bonch-Osmolovskaya, E. A., Jeanthon, C. \& Stackebrandt, E.
(2004). Caminibacter profundus sp. nov., a novel thermophile of Nautiliales ord. nov. within the class 'Epsilonproteobacteria', isolated from a deep-sea hydrothermal vent. Int J Syst Evol Microbiol 54, 41-45.

Porter, K. G. \& Feig, Y. S. (1980). The use of DAPI for identifying and counting microflora. Limnol Oceanogr 25, 943-948.

Takai, K. \& Horikoshi, K. (2000). Thermosipho japonicus sp. nov., an extremely thermophilic bacterium isolated from a deep-sea hydrothermal vent in Japan. Extremophiles 4, 9-17.

Takai, K., Inoue, A. \& Horikoshi, K. (1999). Thermaerobacter marianensis gen. nov., sp. nov., an aerobic extremely thermophilic marine bacterium from the 11,000 $\mathrm{m}$ deep Mariana Trench. Int J Syst Bacteriol 49, 619-628.

Takai, K., Komatsu, T. \& Horikoshi, K. (2001). Hydrogenobacter subterraneus sp. nov., an extremely thermophilic, heterotrophic bacterium unable to grow on hydrogen gas, from deep subsurface geothermal water. Int J Syst Evol Microbiol 51, 1425-1435.

Takai, K., Inagaki, F., Nakagawa, S., Hirayama, H., Nunoura, T., Sako, Y., Nealson, K. H. \& Horikoshi, K. (2003a). Isolation and phylogenetic diversity of members of previously uncultivated $\varepsilon^{-}$ Proteobacteria in deep-sea hydrothermal fields. FEMS Microbiol Lett 218, 167-174.

Takai, K., Kobayashi, H., Nealson, K. H. \& Horikoshi, K. (2003b). Deferribacter desulfuricans sp. nov., a novel sulfur-, nitrate- and arsenate-reducing thermophile isolated from a deep-sea hydrothermal vent. Int J Syst Evol Microbiol 53, 839-846.

Takai, K., Nakagawa, S., Sako, Y. \& Horikoshi, K. (2003c). Balnearium lithotrophicum gen. nov., sp. nov., a novel thermophilic, strictly anaerobic, hydrogen-oxidizing chemolithoautotroph isolated from a black smoker chimney in the Suiyo Seamount hydrothermal system. Int J Syst Evol Microbiol 53, 1947-1954.

Takai, K., Nealson, K. H. \& Horikoshi, K. (2004a). Hydrogenimonas thermophila gen. nov., sp. nov., a novel thermophilic, hydrogenoxidizing chemolithoautotroph within the $\varepsilon$-Proteobacteria, isolated from a black smoker in a Central Indian Ridge hydrothermal field. Int J Syst Evol Microbiol 54, 25-32.

Takai, K., Oida, H., Suzuki, Y., Hirayama, H., Nakagawa, S., Nunoura, T., Inagaki, F., Nealson, K. H. \& Horikoshi, K. (2004b). Spatial distribution of marine crenarchaeota group $\mathrm{I}$ in the vicinity of deep-sea hydrothermal systems. Appl Environ Microbiol 70, 2404-2413.

Tamaoka, J. \& Komagata, K. (1984). Determination of DNA base composition by reversed-phase high-performance liquid chromatography. FEMS Microbiol Lett 25, 125-128.

Tsunogai, U., Kouzuma, F., Nakayama, N., Gamo, T. \& Kaneko, M. (2002). Development of multi-bottle gas-tight sampler WHATS for sampling sea-floor venting fluids. JAMSTEC J Deep Sea Res 21, 91-95. (in Japanese with an English abstract).

Zillig, W., Holz, I., Janekovic, D. \& 7 other authors (1990). Hyperthermus butylicus, a hyperthermophilic sulfur-reducing archaebacterium that ferments peptides. J Bacteriol 172, 3959-3965. 